\title{
Hybrid anthracycline antibiotics: production of new anthracyclines by cloned genes from Streptomyces purpurascens in Streptomyces galilaeus
}

\author{
Jarmo Niemi, ${ }^{1,2}+$ Kristiina Ylihonko, ${ }^{1,2} \ddagger$ Juha Hakala, ${ }^{1} \$ Raimo Pärssinen, ${ }^{1} \$$ \\ Anja Kopio' and Pekka Mäntsälä
}

Author for correspondence: Jarmo Niemi. Tel: +35821 6336856. Fax: +358216336860.

e-mail: janiemi@,finabo.abo.fi (Internet), janiemi@finabo (Bitnet).

1 Leiras OY, PO Box 415, FIN20101, Turku, Finland

2 Department of Biochemistry and Food Chemistry, University of Turku, Vatselankatu 2, FIN20500, and Tykistökatu 6, FIN-20520, Turku,

Finland

\begin{abstract}
A DNA segment cloned from Streptomyces purpurascens ATCC 25489 close to a region that hybridized to a probe containing part of the actinorhodin polyketide synthase caused S. galilaeus ATCC 31615 to produce new anthracyclines. When transformed with certain sub-clones of this segment, the host produced glycosides of $\varepsilon$-rhodomycinone, $\beta$-rhodomycinone, 10demethoxycarbonylaklavinone and 11-deoxy- $\beta$-rhodomycinone in addition to those of aklavinone, the natural anthracyclines of S. galilaeus. The first two compounds are $S$. purpurascens products and the other two are novel compounds that conceptually are structural hybrids between $S$. galilaeus and S. purpurascens products. Three glycosides of one of the novel aglycones, 11deoxy- $\beta$-rhodomycinone, were purified and found to possess cytotoxic activity against L1210 mouse leukaemia cells. Separate regions of the cloned S. purpurascens DNA are responsible for modification of the $S$. galilaeus host product at the 10- and 11-positions.
\end{abstract}

Keywords: Streptomyces purpurascens, anthracycline antibiotics, hybrid antibiotics, cloning

\section{INTRODUCTION}

Anthracyclines are an important group of antibiotics used in cancer chemotherapy. Most of them are either actinomycete metabolites or their semi-synthetic derivatives. The complexity of their structures has made syntheses difficult, and has restricted the development and testing of new members of this group. Natural anthracycline aglycones are produced by the polyketide pathway (Eckardt \& Wagner, 1988). We sought to apply the principle of hybrid antibiotics (Hopwood, 1981; Hopwood et al., 1985b) to the search for new anthracycline molecules.

Aklavinone is a precursor of the aglycones of most

†Present address: Department of Biochemistry and Food Chemistry, University of Turku, Arcanum, Vatselankatu 2, FIN-20500, Turku, Finland.

\$Present address: Department of Biochemistry and Food Chemistry, University of Turku, Tykistökatu 6, FIN-20520, Turku, Finland.

SPresent address: Centre for Biotechnology, University of Turku, Tykistökatu 6, BioCity, FIN-20520, Turku, Finland.

Abbreviation: tsr, thiostrepton. anthracyclines (Eckardt \& Wagner, 1988). Producers of other anthracyclines should contain the enzymes that modify aklavinone to these anthracyclines. The aklavinone glycoside producer, Streptomyces galilaeus (Oki et al., 1975; Fujiwara et al., 1980), should therefore be an ideal host for the production of hybrid anthracycline antibiotics. The strategy used was, firstly, to identify modifying genes by cloning biosynthetic clusters from other anthracycline producers by cross-hybridization; the probe used was a conserved segment of the actinorhodin biosynthetic genes (Malpartida et al., 1987). Portions of the clusters were then transferred into $S$. galilaeus to identify genes causing the production of novel compounds in combination with the aklavinone biosynthetic genes of the host.

\section{METHODS}

Bacteria and plasmids. The organisms and vectors are listed in Table 1.

General recombinant DNA methods. Standard methods (Maniatis $e t$ al., 1982; Hopwood $e t$ al., 1985a) were used, with the exceptions described below. Plasmids were isolated by the 
Table 1. Bacteria and vectors used

\begin{tabular}{|c|c|c|c|c|}
\hline Designation & & Reference & Source & Notes \\
\hline Streptomyces galilaeus & ATCC 31615 & Fujiwara et al. (1980) & ATCC, Rockville, MD, USA & \\
\hline Streptomyces galilaeus & $\mathrm{H} 067^{*}$ & & K. Ylihonko (unpublished) & \\
\hline Streptomyces purpurascens & ATCC 25489 & Shirling \& Gottlieb (1969) & ATCC, Rockville, MD, USA & \\
\hline Streptomyces lividans & TK24 & Hopwood et al. (1985a) & $\begin{array}{l}\text { D. A. Hopwood, John } \\
\text { Innes Institute, Norwich }\end{array}$ & \\
\hline Eschericbia coli & GM2163 & Raleigh et al. (1988) & $\begin{array}{l}\text { E. coli Genetic } \\
\text { Stock Center } \dagger\end{array}$ & \\
\hline Escherichia coli & NM538 & Frischauf et al. (1983) & Promega & \\
\hline Bacteriophages & $\begin{array}{l}\lambda \mathrm{EMBL} 3 \\
\text { iEMBL4 }\end{array}$ & $\begin{array}{l}\text { Frischauf et al. (1983) } \\
\text { Frischauf et al. (1983) }\end{array}$ & $\begin{array}{l}\text { Promega } \\
\text { Amersham }\end{array}$ & \\
\hline \multirow[t]{2}{*}{ Plasmids } & $\begin{array}{l}\text { pIJ486 } \\
\text { pIJ487 } \\
\text { pIJ2345 } \\
\text { pACM5 }\end{array}$ & $\left.\begin{array}{l}\text { Ward et al. }(1986) \\
\text { Ward } \text { et al. }(1986) \\
\text { Malpartida et al. (1987) }\end{array}\right\}$ & $\begin{array}{l}\text { D. A. Hopwood, John } \\
\text { Innes Institute, Norwich }\end{array}$ & $\begin{array}{l}\text { actI probe } \\
\text { acm probe: in pBR322 } \\
\text { (Bolivar } \text { et al., 1977) }\end{array}$ \\
\hline & pRDM6 & This work & & \\
\hline
\end{tabular}

* H067 was produced from ATCC 31615 by NTG mutagenesis using a modification of the method of Baltz (1986), and selected for lysozyme sensitivity.

† E. coli Genetic Stock Center, Department of Biology 255 OML, Yale University, New Haven, USA.

alkaline lysis method (Kieser, 1984) unless otherwise stated. Restriction fragments were isolated from agarose gels using the GeneClean system (Bio 101).

Preparation of hybridization probes and hybridization conditions. The actI probes were the $2.2 \mathrm{~kb} \mathrm{BamHI}$ fragment or the $0.8 \mathrm{~kb} \mathrm{Bg} / \mathrm{II}$ fragment (designated act I0.8) from $\mathrm{pIJ} 2345$. The acm probe was the $3 \mathrm{~kb} \mathrm{Bam} \mathrm{HI} \mathrm{fragment} \mathrm{from} \mathrm{pACM5.} \mathrm{The}$ plasmids were isolated by neutral lysis, followed by caesium chloride/ethidium bromide gradient centrifugation, isopropanol extraction and ethanol precipitation. The probe fragment was isolated by preparative agarose gel electrophoresis after digestion with the appropriate restriction enzyme; about $100 \mathrm{ng}$ was labelled with $50 \mu \mathrm{Ci} \quad\left[\alpha^{32}\right.$-P]ATP $\left[3000 \mathrm{Ci} \mathrm{mmol}^{-1}\right.$ (111 $\left.\mathrm{TBq} \mathrm{mmol}^{-1}\right)$ ] by random priming (Feinberg \& Vogelstein, 1983, 1984), and the labelled probe was separated from unincorporated label by chromatography on Sephadex G-25. Membranes were prehybridized for at least $6 \mathrm{~h}$ at $65^{\circ} \mathrm{C}$ in $1 \%$ (w/v) SDS, $1 \mathrm{M} \mathrm{NaCl}, 5 \times$ Denhardt's solution and $100 \mu \mathrm{g}$ calf thymus DNA ml${ }^{-1}$ before addition of the denatured probe and a further $100 \mu \mathrm{g}$ carrier DNA $\mathrm{ml}^{-1}$. Hybridization was performed for at least $16 \mathrm{~h}$. The membranes were washed twice with $100 \mathrm{ml} 2 \times \mathrm{SSC}(1 \times \mathrm{SSC}$ is $0.15 \mathrm{M} \mathrm{NaCl}, 0.015 \mathrm{M} \mathrm{Na}$ citrate, $\mathrm{pH} 7.0$ ) plus $1 \% \mathrm{SDS}$ at room temperature for $5 \mathrm{~min}$, and twice with $300 \mathrm{ml}$ of the same solution at $65^{\circ} \mathrm{C}$ for $30 \mathrm{~min}$. They were subsequently autoradiographed.

Isolation of total DNA from S. galilaeus and S. purpurascens. Total DNA was isolated by a modification of the method of Hopwood et al. (1985a) from cultures grown in $50 \mathrm{ml}$ SGYEME medium. To prepare SGYEME medium, a solution containing Difco yeast extract $\left(3 \mathrm{~g} \mathrm{l}^{-1}\right)$, Difco Bacto-peptone $\left(5 \mathrm{~g} \mathrm{t}^{-1}\right)$, Oxoid malt extract $\left(3 \mathrm{~g} \mathrm{l}^{-1}\right)$, glucose $\left(10 \mathrm{~g} \mathrm{l}^{-1}\right)$ and sucrose $\left(100 \mathrm{~g} \mathrm{l}^{-1}\right)$ was autoclaved and supplemented with $2 \mathrm{ml}$ sterile $2 \mathrm{M} \mathrm{MgCl}_{2} \mathrm{l}^{-1}$ and $80 \mathrm{ml}$ sterile $10 \%\left(\mathrm{w} / \mathrm{v}\right.$ ) glycine solution $\mathrm{l}^{-1}$. Cultures were incubated in $250 \mathrm{ml}$ Erlenmeyer flasks, each with a steel spring baffle, at $30^{\circ} \mathrm{C}$ for $50 \mathrm{~h}$. In phenol extractions, samples were mixed by careful inversion instead of vortexing; solutions containing DNA were transferred with a wide-bore pipette. DNA was spooled on a glass rod after layering the aqueous solution with 1 vol. isopropanol. The precipitate was dipped in $70 \%(\mathrm{v} / \mathrm{v})$ ethanol, dried in vacuo for 5-10 min, and dissolved in 1-2 ml TE buffer (Maniatis et al., 1982). The concentration and molecular size of the DNA were determined by electrophoresis in 0.3-0.6\% agarose gels.

Preparation of $\lambda$ gene banks from $S$. galilaeus and $S$. purpurascens genomic DNA. Genomic DNA $(>30 \mathrm{~kb})$ prepared as above was digested partially with Sau3AI and fractionated by sucrose gradient centrifugation. Fractions of about $20 \mathrm{~kb}$ were ethanol precipitated and ligated with $\lambda$ vector arms prepared with BamHI cohesive ends ( $\lambda$ EMBL3 with $S$. galilaeus DNA, $\lambda$ EMBL4 with $S$. purpurascens DNA.) Ligations were monitored by agarose gel electrophoresis in $0.3 \%$ agarose, and packaged into $\lambda$ particles (Rosenberg et al., 1985; Rosenberg, 1987).

Isolation and characterization of hybridizing clones. The prepared $\lambda$ gene banks were plated using Escherichia coli GM2163 as host on $150 \mathrm{~mm}$ diameter Petri dishes at a density of 4000-10000 plaques per plate, and two replicate filters were lifted from each plate using nylon membranes (Colony/Plaque Screen, DuPont NEN) according to the manufacturer's instructions. Plaques giving matching hybridization signals on duplicate filters were picked, purified by plating the eluted phage at low plaque density and repeating the hybridization screening, and used to prepare phage stocks by confluent plate lysis. Phage DNA was prepared as described by Kaslow (1986), except that it was precipitated with isopropanol.

The $\lambda$ clone inserts were restriction mapped by single and double digestion; assignment of fragments was confirmed by Southern hybridization of the digested DNA.

Subcloning in Streptomyces. Fragments were isolated from $\lambda$ clones by preparative gel electrophoresis followed by GeneClean treatment. pIJ486 was linearized with suitable restriction 
enzyme(s), treated with calf intestinal alkaline phosphatase where the cohesive ends were rejoinable, and ligated with the isolated fragments using T4 DNA ligase. S. lividans was transformed as described by Hopwood et al. (1985a). Mycelium of $S$. galilaeus used for transformation was grown in SGYEME instead of YEME, and regeneration plates were overlaid with thiostrepton (tsr) solution after $40-48 \mathrm{~h}$. Plasmid DNA from $S$. lividans transformed $S$. galilaeus at a frequency of about $1 \mu \mathrm{g}^{-1}$, and from $S$. galilaeus at about $10^{4} \mu \mathrm{g}^{-1}$.

Detection of anthracycline antibiotics produced by $S$. galilaeus. $S$. galilaeus strains were grown at $28.5^{\circ} \mathrm{C}$ in $250 \mathrm{ml}$ Erlenmeyer flasks containing $60 \mathrm{ml} \mathrm{E} 1$ medium $\left[\mathrm{g} \mathrm{l}^{-1}\right.$ : glucose, 20; soluble starch, 20; Pharmamedia (Traders' Mill Protein Co., Fort Worth, Texas), 5 ; yeast extract, $2 \cdot 5 ; \mathrm{K}_{2} \mathrm{HPO}_{4} .3 \mathrm{H}_{2} \mathrm{O}, 1 \cdot 3$; $\mathrm{MgSO}_{4} .7 \mathrm{H}_{2} \mathrm{O}, 1 ; \mathrm{NaCl}, 3 ; \mathrm{CaCO}_{3}, 3$; in tap water, $\mathrm{pH}$ adjusted to $7 \cdot 5]$ ) using high aeration (300 r.p.m.). With plasmid-containing strains, thiostrepton (tsr) was added at $5 \mu \mathrm{g} \mathrm{ml}^{-1}$.

For screening novel products, S. galilaeus was grown for $7 \mathrm{~d}$, after which a $1 \mathrm{ml}$ sample was centrifuged; the cell pellet was extracted with $500 \mu \mathrm{l}$ toluene/methanol $(1: 1, \mathrm{v} / \mathrm{v})$ and $250 \mu \mathrm{l}$ $0 \cdot 1 \mathrm{M}$ sodium phosphate buffer, $\mathrm{pH} 7 \cdot 0$, was mixed with the extract. After centrifugation a sample of the toluene phase was applied to a TLC plate (Kieselgel $60 \mathrm{~F}_{254}$, Merck) and developed with toluene/ethyl acetate/methanol/formic acid (50:50:15: 10 , by vol.).

To detect aglycones of the glycosides produced, the toluene phase obtained above was extracted with $0.1 \mathrm{M} \mathrm{HCl}$, and the aqueous phase hydrolysed for $30 \mathrm{~min}$ in a boiling water bath. The aglycones were extracted into toluene, and analysed by TLC on oxalic-acid-treated silica (see below).

Production of hybrid glycosides. Hybrid $S$. galilaeus strains

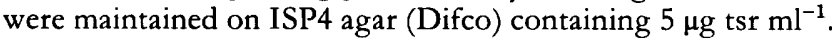
To produce a seed culture, $60 \mathrm{ml}$ medium E1 containing tsr in a $250 \mathrm{ml}$ Erlenmeyer flask was inoculated with a colony and grown for $4 \mathrm{~d}$ at $28.5^{\circ} \mathrm{C}$ in a rotary shaker at 330 r.p.m. The culture was transferred to 5.51 medium E1 sterilized in a 71 fermenter and supplemented with tsr (to $5 \mu \mathrm{g} \mathrm{ml}^{-1}$ ) and antifoam ( $5 \mathrm{ml}$ polypropylene glycol $\mathrm{P} 2000$, Fluka). The production culture was grown for $5 \mathrm{~d}$ at $30^{\circ} \mathrm{C}, 350$ r.p.m., and with aeration at $61 \mathrm{~min}^{-1}$. The fermenter contents were transferred to a $10 \mathrm{l}$ vessel and stirred for $45 \mathrm{~min}$ with $400 \mathrm{~g}$ Celatom (Johns-Manville), $47 \mathrm{~g} \mathrm{Na}{ }_{2} \mathrm{HPO}_{4} \cdot 2 \mathrm{H}_{2} \mathrm{O}, 24 \cdot 4 \mathrm{~g}$ citric acid, $500 \mathrm{ml}$ water and 31 methyl ethyl ketone. The extract was vacuum-filtered, and the phases were allowed to separate overnight after addition of $500 \mathrm{~g} \mathrm{NaCl}$. The organic phase was dried with $400 \mathrm{~g} \mathrm{Na}_{2} \mathrm{SO}_{4}$.

Isolation and hydrolysis of the glycoside fraction. The organic phase was evaporated in vacuo, redissolved in $150 \mathrm{ml}$ toluene, and mixed with $150 \mathrm{ml}$ isopropanol, $150 \mathrm{ml} 0.1 \mathrm{M} \mathrm{HCl}$ and $75 \mathrm{ml}$ hexane. The lower phase was removed and extracted with $40 \mathrm{ml}$ dichloromethane. The dichloromethane phase was further

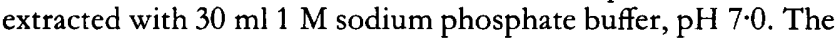
upper phase of the first extraction was mixed with $75 \mathrm{ml}$ isopropanol and $150 \mathrm{ml} 0.1 \mathrm{M} \mathrm{HCl}$; the lower phase was then treated in the same way as the lower phase from the first extraction. The combined dichloromethane extracts were evaporated in vacuo and the residue, redissolved in toluene, was extracted with 1 vol. $0.1 \mathrm{M} \mathrm{HCl}$. The aqueous phase was heated at $85^{\circ} \mathrm{C}$ for $2 \mathrm{~h}$, then extracted three times with 0.5 vol. toluene. The combined toluene extracts were washed with an equal volume of $0 \cdot 1 \mathrm{M}$ sodium phosphate buffer, $\mathrm{pH} 7 \cdot 0$, and evaporated to dryness. The aglycone products so obtained were redissolved in a small volume of toluene.

Fractionation of the aglycone mixture. The aglycones in the toluene solution were purified by chromatography on a $4 \times 20 \mathrm{~cm}$ column of oxalic-acid-treated silica (Brockmann $e t$ al., 1965). Fractions eluted with $10 \%(\mathrm{v} / \mathrm{v})$ acetone in toluene were analysed by TLC as described below. Those containing two components were fractionated again on a $1.5 \times 50 \mathrm{~cm}$ column with $5 \%$ acetone in methylene chloride. The aglycones obtained were crystallized by dissolving in boiling methanol, concentrating the solution under a stream of nitrogen until crystals began to form, and allowing the solution to cool.

Large-scale fermentation of the hybrid strain and purification of aglycone IV. S. galilaeus ATCC 31615(pRDM6) was grown for $7 \mathrm{~d}$ in $550 \mathrm{l} \mathrm{E1}$ medium containing tsr in a $750 \mathrm{l}$ pilot fermenter; the culture was hydrolysed in the fermenter by adjusting the medium to $\mathrm{pH} 2$ and heating to $85^{\circ} \mathrm{C}$ for $2 \mathrm{~h}$. The hydrolysate was extracted with methyl ethyl ketone, and the extract was concentrated by vacuum distillation. A crude extract obtained was dissolved in 31 toluene.

To $500 \mathrm{ml}$ of the crude extract, representing the product from about $100 \mathrm{l}$ culture from the fermenter, $100 \mathrm{~g}$ of oxalic-acidtreated silica was added. After stirring, the silica was recovered on a sintered glass filter, and washed twice with $500 \mathrm{ml}$ toluene. Crude aglycone IV was eluted from the silica with acetone. The eluate was concentrated in vacuo, and dissolved in $100 \mathrm{ml}$ methanol. The insoluble material was removed, and the solution was evaporated in vacuo. The residue was dissolved in $100 \mathrm{ml}$ toluene; $100 \mathrm{ml}$ hexane was added, and the clarified solution was again evaporated in vacuo. Aglycone IV in the residue was dissolved in toluene and chromatographed on oxalic-acidtreated silica on a $4 \times 20 \mathrm{~cm}$ column. Fractions eluted with $10 \%$ acetone in toluene were analysed by TLC on oxalic-acid-treated silica plates; those containing mostly aglycone IV were extracted with 1 vol. $0 \cdot 1 \mathrm{M}$ sodium phosphate buffer, $\mathrm{pH} 7 \cdot 0$, to remove oxalic acid, dried over $\mathrm{Na}_{2} \mathrm{SO}_{4}$, evaporated to dryness, and crystallized from methanol. The yield of pure aglycone IV was $10 \cdot 1 \mathrm{mg}$.

Purification of aglycone IV glycosides. A portion $(2 \mathrm{ml})$ of the glycoside solution obtained above was applied as a band to a TLC plate and developed with chloroform/methanol/acetic acid (20:5:1, by vol.). Yellow products at $R_{F}$ values of 0.40 (IV A) and 0.55 (IV B) were recovered.

About $200 \mathrm{ml}$ glycosidic extract was extracted with $0.05 \mathrm{M} \mathrm{HCl}$, and the aqueous phase was incubated for $30 \mathrm{~min}$ at $55^{\circ} \mathrm{C}$. The solution was neutralized with $20 \mathrm{ml} 1 \mathrm{M}$ sodium phosphate buffer, $\mathrm{pH} 7 \cdot 0$, and extracted three times with chloroform. The combined chloroform extracts were evaporated and the residue, dissolved in $20 \mathrm{ml}$ dichloromethane, was chromatographed on a Kieselgel 60 (Merck) column with dichloromethane/methanol/ acetic acid (100:20:1, by vol.). Fractions containing a yellow product with an $R_{F}$ value of $0 \cdot 21$ (IV T) by TLC were pooled. Acetic acid was removed by extracting with water to which $\mathrm{NaOH}$ was added until the aqueous phase was neutral. The dichloromethane phase was evaporated and the residue, dissolved in $2 \mathrm{ml}$ methanol and $20 \mathrm{ml}$ toluene, was rechromatographed on a silical gel column with toluene/methanol $(1: 1$, $\mathrm{v} / \mathrm{v}$ ) as eluent.

Cytotoxicity testing. The cytotoxicity of anthracycline glycosides was tested in vitro against L1210 mouse leukaemia cells using the method of Matsuzawa et al. (1981) modified for microtitre plates, and with cell numbers determined using a Coulter cell counter.

Analytical methods. Anthracycline glycosides were analysed by TLC on Kieselgel $60 \mathrm{~F}_{254}$ using chloroform/methanol/acetic acid (30:4:1, by vol., first dimension) and toluene/ethyl acetate/methanol/formic acid (50:50:15:3, by vol., second 


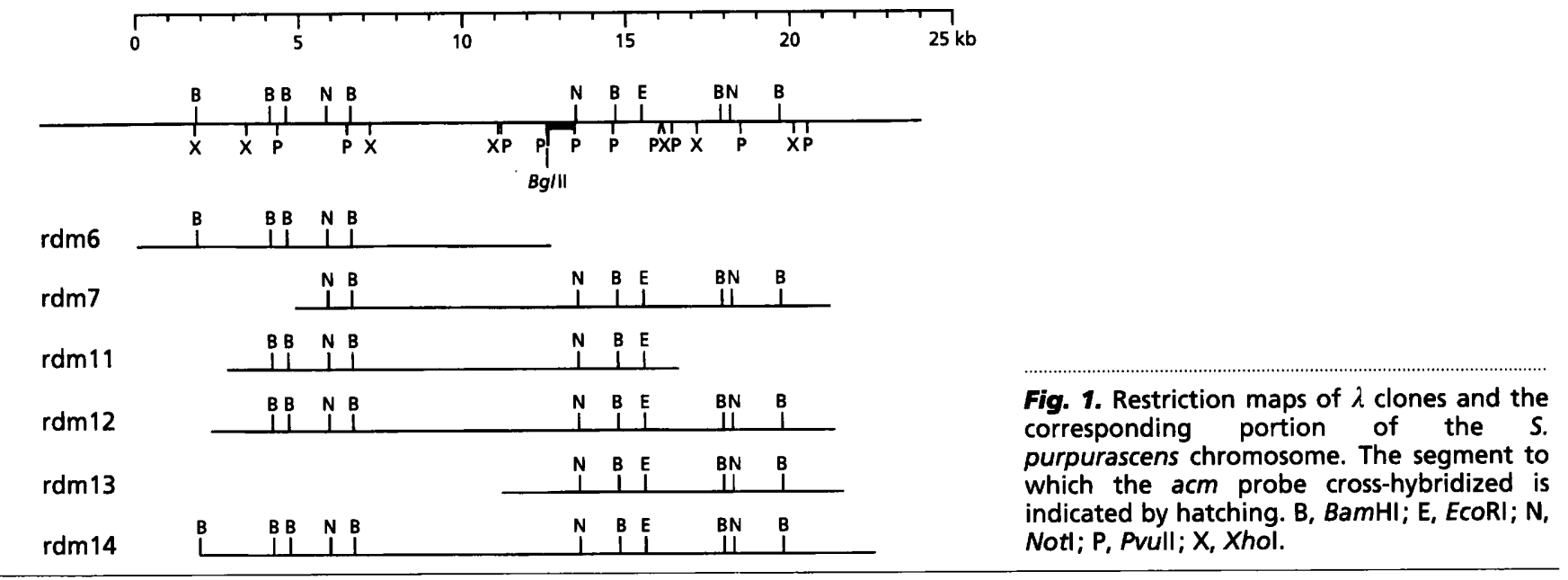

dimension). Aglycones were analysed by TLC on oxalic-acidtreated silica as follows: Kieselgel $60 \mathrm{~F}_{254}$ plates were dipped in $0.25 \mathrm{M}$ oxalic acid, dried in the oven at $110^{\circ} \mathrm{C}$ and developed with chloroform/acetone $(10: 1, \mathrm{v} / \mathrm{v}) . \mathrm{NaHCO}_{3}$-treated plates were similarly impregnated with a $0.5 \mathrm{M}$ solution. NMR spectra were recorded with a $200 \mathrm{MHz}$ Bruker AM-200 instrument, and mass spectra with a VG Analytical $7070 \mathrm{E}$ Organic Mass Spectrometer using chemical ionization with methane or isobutane.

Construction of the deletion series. Unidirectional deletions of cloned $S$. purpurascens DNA were made by the method of Henikoff $(1984,1987)$ using plasmid DNA isolated from $S$. galilaeus. After deletion of DNA, the religated plasmid mixture was introduced by transformation into $S$. galilaeus.

\section{RESULTS}

\section{Cloning a fragment from S. galilaeus homologous to actl of S. coelicolor}

As has been observed for other anthracycline producers (Stutzman-Engwall \& Hutchinson, 1989), probes from the actI region of the actinorhodin polyketide synthase gene cluster hybridized to more than one Bam HI fragment of $S$. galilaeus DNA. Signals were detected for $3 \mathrm{~kb}$ and $9 \mathrm{~kb}$ fragments. A $\lambda$ gene bank was constructed from $S$. galilaeus total DNA. For efficient cloning of $S$. galilaeus DNA in E. coli, it was necessary to use a $m c r B^{-}$host, GM 2163 (Raleigh et al., 1988). The clones were then propagated in NM538. Plaques hybridizing with the act 10.8 probe were purified, and a $3 \mathrm{~kb}$ Bam HI hybridizing DNA fragment from one of them was subcloned into the BamHI site of pBR322, producing pACM5. The insert in this plasmid, designated acm, hybridized with unique 3,8 and $3 \mathrm{~kb} \mathrm{Bam} \mathrm{HI}$ fragments from S. galilaeus, S. purpurascens and $S$. peucetius, respectively.

\section{Hybrid anthracycline production by cloned $S$. purpurascens DNA}

A $\lambda$ gene bank from $S$. purpurascens was prepared in the same manner as that from $S$. galilaeus; six hybridizing clones were isolated using the acm probe. Restriction mapping showed that these clones covered $23 \mathrm{~kb}$ of contiguous DNA (Fig. 1).

Various restriction fragments from the clones were transferred into $S$. galilaeus by cloning into the polylinker region of the high copy number plasmid pI J486. Because S. galilaeus appears to have a relatively strong restriction barrier, the constructions were first made in S. lividans and then used to transform S. galilaeus. S. galilaeus $\mathrm{H} 067$, which is more easily transformed than the ATCC 31615 strain, but is a poor producer of anthracyclines, was used as intermediate host in most cases.

pRDM6, which contains the $12.6 \mathrm{~kb}$ insert of $\lambda \mathrm{rdm} 6$ subcloned using the flanking vector EcoRI sites, caused the production of anthracyclines that clearly differed from those of the host. On hydrolysis, they yielded several aglycones in addition to aklavinone, the aglycone produced by the host. Cultures of $S$. galilaeus containing pRDM6 in media without tsr selection rapidly lost their ability to produce aglycones other than aklavinone. When pRDM6 isolated from the original transformant was used to transform plasmid-free $S$. galilaeus, the new transformants produced the same additional aglycones, implicating PRDM6 in their production.

\section{Purification and identification of aglycones produced by the hybrid strain}

Cultures of the hybrid strain contained a complex spectrum of products: two-dimensional TLC of the crude glycoside fraction showed at least 28 components apparently containing an anthracyclinone chromophore. The mixture was hydrolysed and the aglycones were fractionated by column chromatography on oxalic-acidtreated silica. Two different solvent systems were used because pairs not resolved with dichloromethane/acetone (Brockmann et al., 1965, but with dichloromethane replacing chloroform) could be resolved with toluene/ acetone. The main fractions were designated $\mathrm{I}-\mathrm{V}$ in the order they eluted; pairs resolved with dichloromethane/ acetone were identified with letters. Thus, seven aglycones 


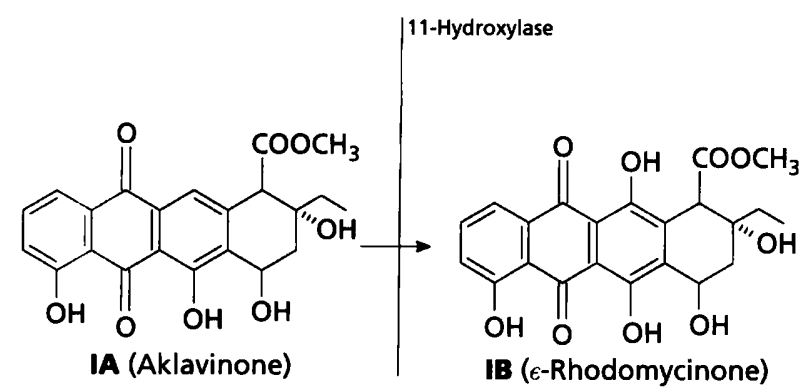<smiles>CCOC(=O)c1cc2c(c(O)c1C(=O)O)C(=O)c1c(O)cccc1C2=O</smiles>

Fig. 2. Observed anthracycline aglycones produced by $S$. galilaeus carrying pRDM6, and enzyme activities expected to be required for their production. The untransformed host produces glycosides of IA (aklavinone), and the gene donor S. purpurascens produces glycosides of IB and IIB ( $\varepsilon$ - and $\beta$-rhodomycinone).

(IA, IB, IIA, IIB, III, IV and V) were resolved (Fig. 2, except III and V). Comparison with authentic aglycones by TLC, mass spectroscopy and proton NMR identified IA, IB and IIB as aklavinone, $\varepsilon$-rhodomycinone and $\beta$ rhodomycinone, respectively.

Mass spectroscopy of IIA using direct chemical ionization (DCI) gave a molecular mass of $354 \mathrm{Da}$. Interpretation of the proton NMR spectrum led to the identification of IIA as 10-demethoxycarbonylaklavinone (Fig. 2). Tanaka et al. (1980) previously prepared this aglycone chemically; their proton NMR data are very similar to ours. Authentic 10-demethoxycarbonylaklavinone (a kind gift of $\mathrm{Dr} \mathrm{H}$. Tanaka, Mercian Corp., Japan) was indistinguishable from IIA by TLC on oxalic-acid-treated silica and on $\mathrm{NaHCO}_{3}$-impregnated silica with chloroform/acetone $(10: 1, v / v)$.

The molecular mass of IV was $370 \mathrm{Da}$, and the proton NMR spectrum was interpreted as that of 11-deoxy- $\beta$ rhodomycinone. Because reference data for this molecule were unobtainable, we compared the ${ }^{13} \mathrm{C}$-NMR spectrum of IV with those of aklavinone and $\beta$-rhodomycinone
Table 2. Chemical shifts and suggested assignment of ${ }^{13} \mathrm{C}$-NMR chemical shifts of aglycone IV, aklavinone and the aglycone portion of $\beta$-rhodomycin A

Reference data are from Oki (1984). Chemical shift data are given in p.p.m. relative to $\left[{ }^{13} \mathrm{C}\right]$ tetramethylsilane.

\begin{tabular}{|cccc|}
\hline $\begin{array}{c}\text { Carbon } \\
\text { no. }\end{array}$ & Aklavinone & $\begin{array}{c}\boldsymbol{\beta} \text {-Rhodomycin } \\
\text { A }\end{array}$ & $\begin{array}{c}\text { Aglycone } \\
\text { IV }\end{array}$ \\
\hline 14 & & $6 \cdot 6$ & $6 \cdot 52$ \\
13 & $6 \cdot 7$ & $32 \cdot 9$ & $29 \cdot 03$ \\
8 & $32 \cdot 5$ & $30 \cdot 5$ & $35 \cdot 38$ \\
16 & $34 \cdot 9$ & & \\
10 & $52 \cdot 6$ & $66 \cdot 7$ & $72 \cdot 10$ \\
7 & $56 \cdot 7$ & $70 \cdot 4$ & $61 \cdot 12$ \\
9 & $62 \cdot 5$ & $71 \cdot 8$ & $73 \cdot 01$ \\
$5 \mathrm{a}$ & $71 \cdot 9$ & $112 \cdot 1$ & $114 \cdot 06$ \\
$4 \mathrm{a}$ & $114 \cdot 7$ & $116 \cdot 0$ & $115 \cdot 99$ \\
1 & $115 \cdot 8$ & $119 \cdot 7$ & $119 \cdot 31$ \\
11 & $120 \cdot 4$ & $157 \cdot 3$ & $120 \cdot 87$ \\
3 & $121 \cdot 5$ & $124 \cdot 9$ & $124 \cdot 33$ \\
$11 \mathrm{a}$ & $124 \cdot 8$ & $111 \cdot 5$ & $131 \cdot 85$ \\
$6 \mathrm{a}$ & $132 \cdot 7$ & $135 \cdot 2$ & $132 \cdot 85$ \\
$12 \mathrm{a}$ & $133 \cdot 1$ & $133 \cdot 3$ & $133 \cdot 41$ \\
2 & $133 \cdot 6$ & $137 \cdot 1$ & $137 \cdot 36$ \\
$10 \mathrm{a}$ & $137 \cdot 7$ & $138 \cdot 7$ & $148 \cdot 25$ \\
6 & $142 \cdot 9$ & $156 \cdot 9$ & $160 \cdot 57$ \\
4 & $161 \cdot 4$ & $162 \cdot 7$ & $161 \cdot 30$ \\
15 & $162 \cdot 8$ & & \\
12 & $171 \cdot 5$ & $186 \cdot 2$ & $181 \cdot 16$ \\
5 & $181 \cdot 3$ & $190 \cdot 7$ & $191 \cdot 93$ \\
\hline & $192 \cdot 8$ & & \\
\hline
\end{tabular}

(Table 2). The chemical shift data support the proposed structure for IV.

The proton NMR spectra of IIA and IV, as well as the ${ }^{13} \mathrm{C}$-NMR spectrum of IV, have been deposited with the British Library Document Supply Centre, Boston Spa, Wetherby, West Yorkshire LS23 7BQ, UK, as Supplementary Publication no. SUP 28027 (4 pages).

On the basis of proton NMR spectra, and the observation that in milder hydrolysis conditions their amounts are much reduced, III and V were identified as 7-epimers of IIA and IV, respectively, and concluded to be artefacts of hydrolysis.

Restriction fragments of the insert in $\lambda \mathrm{rdm} 6$ were subcloned in pIJ486. The smallest tested restriction fragment to cause the production of all the hybrids was the $6.2 \mathrm{~kb}$ Bam HI-Sau3AI (-EcoRI) fragment designated EB3 in Fig. 3.

To locate more accurately the genes responsible for the various modifications, a deletion series was constructed from the clone containing EB3 in pI J486. Fig. 3 shows the aglycones produced by $S$. galilaeus transformed with various members of the deletion series. The largest fragment causing the production of all hybrids is $1-3 \mathrm{p} 1$ $(5.0 \mathrm{~kb})$. Further shortening of the fragments eliminated 

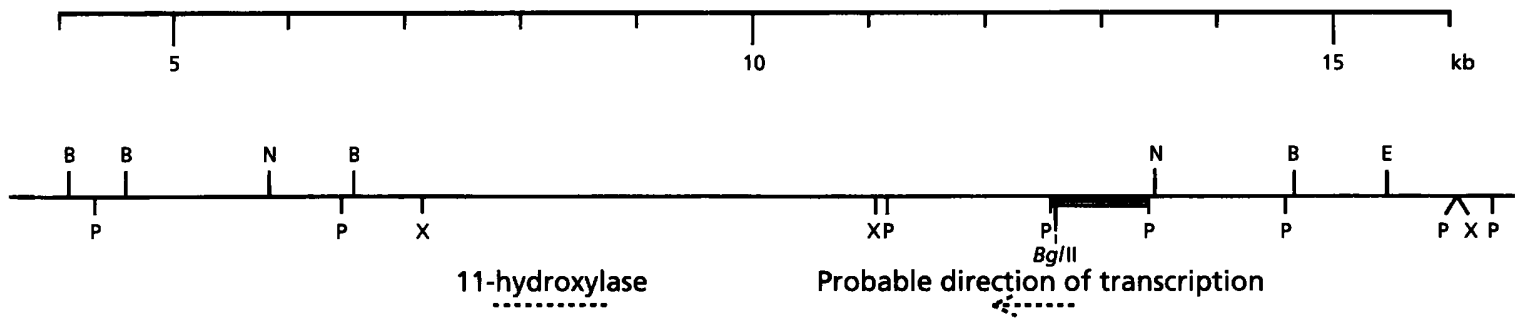

Aglycones:

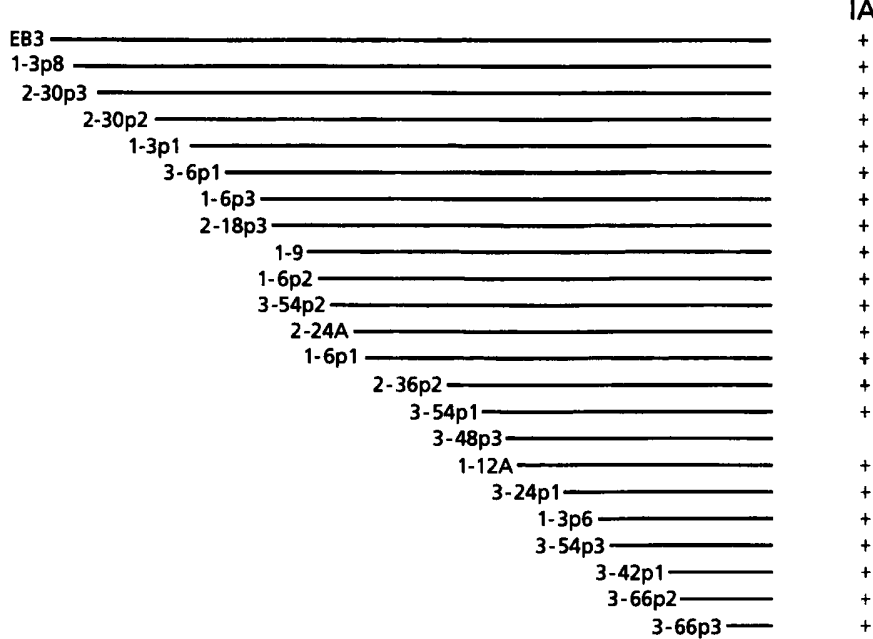

IA IB IIA IIB IV

$\begin{array}{llll}+ & + & + & + \\ + & + & + & + \\ + & + & + & + \\ + & + & + & + \\ + & + & + & + \\ & + & & + \\ & + & & + \\ & + & & + \\ & + & & + \\ & + & & + \\ & + & & + \\ & + & & +\end{array}$

Fig. 3. Deletion series of the $6.2 \mathrm{~kb}$ BamHI-Sau3Al (-EcoRI) fragment of $\lambda$ rdm6 and aglycones produced by $S$. galilaeus carrying the remaining fragments in plJ486.

production of both aglycones with an 11-hydroxyl group. With fragments shorter than $3.6 \mathrm{~kb}(2-24 \mathrm{~A})$ no hybrid production was detected by TLC.

The EB3 fragment was also subcloned into $\mathrm{pI}$ J487, which has the opposite orientation of the polylinker region from pIJ486. S. galilaeus transformed with this construct produced only glycosides of aklavinone (IA) and $\varepsilon$ thodomycinone (IB). The same products were observed when the $8.1 \mathrm{~kb} \mathrm{BamHI}$ fragment $(6.5-14.6 \mathrm{~kb}$, Fig. 1) was subcloned in $\mathrm{pIJ} 486$.

\section{Purification and biological activity of some glycosides of aglycone IV}

Three glycosidic components, IV A, IV B and IV T, were purified from the glycosidic mixture. On hydrolysis, all of them yielded aglycone IV; on mild hydrolysis IV A and IV $B$ yielded IV $T$. The mass spectrum of IV T shows a molecular ion peak at 528, corresponding to aglycone $\mathrm{IV}+$ rhodosamine. When IV A and IV B were added to cultures of $S$. galilaeus ATCC 31615 under conditions where biotransformation of aclacinomycin B to aclacinomycin A takes place (Hoshino et al., 1983), IV B was transformed into IV $\mathrm{A}$, and the latter remained unchanged.

The concentrations of the glycosides were estimated assuming molar extinction values similar to aclacinomycin $\mathrm{A}$, and their in vitro cytotoxicity against mouse leukaemia cell line $\mathrm{L} 1210$ was tested. The potencies of all three $\left(\mathrm{ED}_{50}\right.$ 75,24 and $22 \mathrm{nmol}^{-1}$ for IV A, IV B and IV T, respectively) were within an order of magnitude, although less, than that of aclacinomycin $\mathrm{A}\left(10 \mathrm{nmol} \mathrm{l}^{-1}\right)$.

\section{DISCUSSION}

Cross-hybridization with actI (Malpartida et al., 1987) again proved successful in the isolation of genes participating in the biosynthesis of a polyketide. The anthracycline modifying genes described in this study were isolated from $S$. purpurascens using a homologous fragment from $S$. galilaeus that had been isolated using actI. Although it has not been shown that this fragment is part of the aklavinone biosynthetic cluster, it also recognizes the $3 \mathrm{~kb} \mathrm{BamHI}$ fragment in S. peucetius which is part of the biosynthetic cluster of $\varepsilon$-rhodomycinone (StutzmanEngwall \& Hutchinson, 1989; K. Ylihonko, unpublished data).

pRDM6 caused $S$. galilaeus to synthesize new anthracycline products. The aglycones identified can be arranged in a plausible biosynthetic pattern (Fig. 2) and could all be produced by enzyme activities expected in $S$. purpurascens, which makes glycosides of $\varepsilon$ - and $\beta$-rhodomycinone. The overall amount of anthracycline glycosides produced by the hybrid strains was similar to that of the host (about $100 \mathrm{mg} \mathrm{l}^{-1}$ ). However, this is divided over a large number of products, so it was not possible to produce enough glycosides for definitive structural determination. By mild 


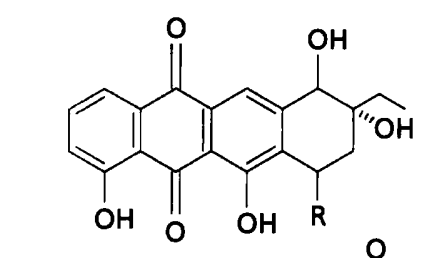<smiles>CC(C)COCOC(C)C(C)O</smiles>

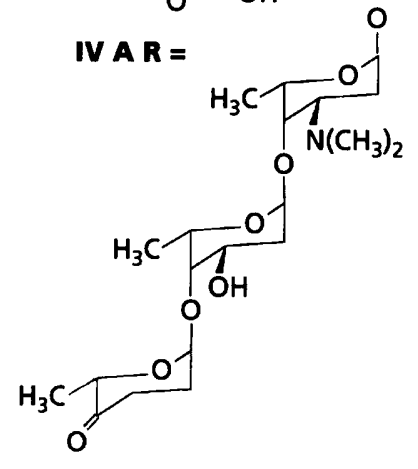

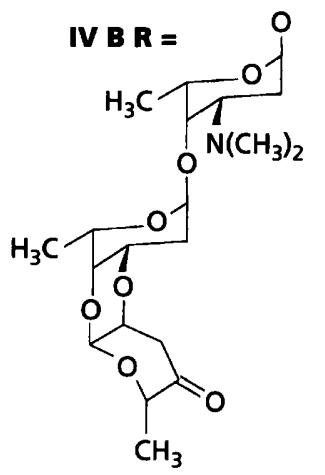

Fig. 4. Proposed structures of the three 11-deoxy- $\beta$ rhodomycinone glycosides purified and tested for biological activity in this work.

hydrolysis, higher anthracycline glycosides yielded predominantly monoglycosylated products. Rhodosamine glycosides could be distinguished from daunosamine glycosides by their partitioning to the toluene phase at $\mathrm{pH} 7 \cdot 0$, and further by the mass spectrum of IV T. We propose that the three glycosides tested for biological activity have the structures shown in Fig. 4 . The cytotoxic activity of these compounds in a simple in vitro test is comparable to that of anthracyclines presently in clinical use (Matsuzawa et al., 1981), but only further tests can show whether these new glycosides could be clinically useful.

Otake et al. (1985) described glycosides of 11-deoxy- $\beta$ rhodomycinone having daunosamine glycosylation; unfortunately further data are not available to us. As far as we know, the 11-deoxy- $\beta$-rhodomycinone glycosides with rhodosamine glycosylation described in this work are new.

The cloned segments of $S$. purpurascens DNA did not cause the large increase in anthracycline production observed when cloned $d n r R_{1}$ and $d n r R_{2}$ segments of $S$. peucetius DNA were introduced into a producing host (Stutzman-Engwall et al., 1992).

Whether production of the new compounds is due to activation of host genes (so-called silent genes: Jones \& Hopwood, 1984) by the cloned DNA cannot be excluded by present data. During strain development of the host in our laboratory, mutants producing 11-hydroxylated anthracyclines have never been seen (these would be clearly observable due to their colour) but mutants producing anthracyclines modified at the 10 position could conceivably have been missed. Preliminary biotransformation experiments using $S$. lividans transformed with PRDM6 and its subclones have not been successful. The fact that the DNA regions causing modifications at the 10- and 11- positions can be separated also speaks against the silent gene hypothesis.

It is remarkable that only the 11-modification was expressed, when the EB3 fragment was inserted in the opposite orientation, or about $1.5 \mathrm{~kb}$ more DNA was included in the insert. We believe, that in the active subclones the 10-modifications are artefactually expressed from a vector promoter or some other cis-acting genetic element. As the insert in pIJ486 and pI J487 is flanked on one side by an efficient transcription terminator (Ward $e t$ al., 1986), the most probable explanation seems to be, that the promoter of the tsr resistance gene in the vector causes transcription as indicated in Fig. 3.

We expected that the regulation of anthracycline biosynthesis would be sufficiently conserved to allow the biosynthesis genes to be expressed in the producer of a related antibiotic. This appeared to be true for the 11-modification, but our results indicate that the 10modifications are not naturally expressed in $S$. galilaeus.

\section{ACKNOWLEDGEMENTS}

We thank the management of Leiras, in particular Dr Klaus Lampi, for the resources to conduct this research. We also thank Dr Juhani Lundell, Dr Hannu Nikander, Dr Juhani Varhiala, Dr Markku Reunanen and Dr Esko Pohjala for participating in the purification and structural analysis of the hybrid products, and Ms Eija Ruuth, Mr Lasse Salminen and Mr Jorma Määttä for expert technical assistance. We thank Professor David A. Hopwood for invaluable advice, help, Streptomyces hosts and vectors, and for critical reading of the manuscript. We express appreciation to Dr Hiroshi Tanaka for a gift of authentic demethoxycarbonylaklavinone. J.N. gratefully acknowledges grants from the Varsinais-Suomi Fund of the Finnish Cultural Foundation and the Jenny and Antti Wihuri Foundation.

\section{REFERENCES}

Baltz, R. H. (1986). Mutagenesis in Streptomyces. In Manual of Industrial Microbiology and Biotechnology, pp. 184-90. Edited by A. L. Demain \& N. A. Solomon. Washington, DC: American Society for Microbiology.

Bolivar, F., Rodriguez, R. L., Greene, P. J., Betlach, M. C., Heyneker, H. L., Boyer, H. W., Crosa, J. H. \& Falkow, S. (1977). Construction and characterization of new cloning vehicles. II. A multipurpose cloning system. Gene 2, 95-113.

Brockmann, H., Niemeyer, J. \& Rode, W. (1965). Rhodomycine, IX; Antibiotica aus Actinomyceten, LII: $\beta$-iso-rhodomycinon. Chem Ber 98, 3145-3152.

Eckardt, K. \& Wagner, C. (1988). Biosynthesis of anthracyclinones. $J$ Basic Microbiol 28, 137-144.

Feinberg, A. P. \& Vogelstein, B. (1983). A technique for radiolabeling DNA restriction endonuclease fragments to high specific activity. Anal Biochem 132, 6-13.

Feinberg, A. P. \& Vogelstein, B. (1984). Addendum: a technique for radiolabeling DNA restriction endonuclease fragments to high specific activity. Anal Biochem 137, 266-267.

Frischauf, A.-M., Lehrach, H., Poustka, A. \& Murray, N. (1983). Lambda replacement vectors carrying polylinker sequences. $J \mathrm{Mol}$ Biol 170, 827-842.

Fujiwara, A., Hoshino, T. \& Tazoe, M. (1980). Process to produce 
aclacinomycins A and B. US Patent 4375511. Published 1 March 1983, priority 27 October 1980.

Henikoff, S. (1984). Unidirectional digestion with exonuclease III creates targeted breakpoints for DNA sequencing. Gene 28, 351-359.

Henikoff, S. (1987). Unidirectional digestion with exonuclease III in DNA sequence analysis. Methods Enzymol 155, 156-165.

Hopwood, D. A. (1981). Future possibilities for the discovery of new antibiotics by genetic engineering. In Beta-Lactam Antibiotics, pp. 585-598. Edited by M. R. J. Salton \& G. D. Shockman. New York: Academic Press.

Hopwood, D. A., Bibb, M. J., Chater, K. F., Kieser, T., Bruton, C. J., Kieser, H. M., Lydiate, D. J., Smith, C. P., Ward, J. M. \& Schrempf, H. (1985a). Genetic Manipulation of Streptomyces: A Laboratory Manual. Norwich: John Innes Foundation.

Hopwood, D. A., Malpartida, F., Kieser, H. M., Ikeda, H., Duncan, J., Fujii, I., Rudd, B. A. M., Floss, H. G. \& Omura, S. (1985b). Production of 'hybrid' antibiotics by genetic engineering. Nature 314, 642-644.

Hoshino, Y., Sekine, Y. \& Fujiwara, A. (1983). Microbial conversion of aclacinomycin B to aclacinomycin A. J Antibiot 36, 1458-1462.

Jones, G. H. \& Hopwood, D. A. (1984). Activation of phenoxazinone synthase expression in Streptomyces lividans by cloned sequences from Streptomyces antibioticus. $J$ Biol Chem 259, 14158-14164.

Kaslow, D. C. (1986). A rapid biochemical method for purifying $\lambda$ DNA from phage lysates. Nucleic Acids Res 14, 6767.

Kieser, T. (1984). Factors affecting the isolation of CCC DNA from Streptomyces lividans and Escherichia coli. Plasmid 12, 19-36.

Malpartida, F., Hallam, S. E., Kieser, H. M., Motamedi, H., Hutchinson, C. R., Butler, M. J., Sugden, D. A., Warren, M., McKillop, C., Bailey, C. R., Humphreys, G. O. \& Hopwood, D. A. (1987). Homology between Streptomyces genes coding for synthesis of different polyketides and its use to clone antibiotic biosynthetic genes. Nature 325, 818-821.

Maniatis, T., Fritsch, E. F. \& Sambrook, J. (1982). Molecular Cloning: A Laboratory Manual. Cold Spring Harbor, NY: Cold Spring Harbor Laboratory.

Matsuzawa, Y., Oki, T., Takeuchi, T. \& Umezawa, H. (1981). Structure-activity relationships of anthracyclines relative to cytotoxicity and effects on macromolecular synthesis in L1210 leukemia cells. J Antibiot 34, 1596-1606.
Oki, T. (1984). Recent developments in the process improvement of production of antitumor anthracycline antibiotics. Adv Biotechnol Processes 3, 163-196.

Oki, T., Matsuzawa, Y., Yoshimoto, A., Numata, K., Kitamura, I., Hori, S., Takamatsu, A., Umezawa, H., Ishizuka, M., Naganawa, H., Suda, H., Hamada, M. \& Takeuchi, T. (1975). New antitumor antibiotics, aclacinomycins A and B. $J$ Antibiot 28, 830-834.

Otake, N., Tatsuta, K., Hayakawa, Y., Otsuki, N. (1985). Anthracycline compounds and antitumor agents containing them. Japanese Patent 62-81398. Application date 3 October 1985.

Raleigh, E. A., Murray, N. E., Revel, H., Blumenthal, R. M., Westaway, D., Reith, A. D., Rigby, P. W. J., Elhai, J. \& Hanahan, D. (1988). Mcr $A$ and $M c r B$ restriction phenotypes of some E. coli strains and implications for gene cloning. Nucleic Acids Res 16, 1563-1575.

Rosenberg, S. M. (1987). Improved in vitro packaging of lambda DNA. Methods Enzymol 153, 95-103.

Rosenberg, S. M., Stahl, M. M., Kobayashi, I. \& Stahl, F. W. (1985). Improved in vitro packaging of coliphage lambda DNA: a onestrain system free from endogenous phage. Gene 38, 165-175.

Shirling, E. B. \& Gottlieb, D. (1969). Cooperative description of type cultures of Streptomyces. IV. Species descriptions from the second, third and fourth studies. Int J Syst Bacteriol 19, 391-512.

Stutzman-Engwall, K. J. \& Hutchinson, C. R. (1989). Multigene families for anthracycline antibiotic production in Streptomyces peucetius. Proc Natl Acad Sci USA 86, 3135-3139.

Stutzman-Engwall, K. J., Otten, S. L. \& Hutchinson, C. R. (1992). Regulation of secondary metabolism in Streptomyces spp. and overproduction of daunorubicin in Streptomyces peucetius. J Bacteriol 174, 144-154.

Tanaka, H., Yoshioka, T., Shimauchi, Y., Matsuzawa, Y., Oki, T. \& Inui, T. (1980). Chemical modification of anthracycline antibiotics. I. Demethoxycarbonylation, 10-epimerization and 4-O-methylation of aclacinomycin A. Antibiot 33, 1323-1330.

Ward, J. M., Janssen, G. R., Kieser, T., Bibb, M. J., Buttner, M. J. \& Bibb, M. J. (1986). Construction and characterization of a series of multi-copy promoter-probe plasmid vectors for Streptomyces using the aminoglycoside phosphotransferase from $\mathrm{Tn} 5$ as indicator. Mol \& Gen Genet 203, 468-478.

Received 13 September 1993; revised 29 November 1993; accepted 12 January 1994. 